\title{
Evaluation of Treated Municipal Wastewater Quality for Irrigation
}

\author{
Abdul Hameed M. Jawad Alobaidy, Mukheled A. Al-Sameraiy, Abass J. Kadhem, Athmar Abdul \\ Majeed
}

Environmental Research Center, University of Technology, Baghdad, Iraq.

Email: jawaddhy@yahoo.co.in,mukheled@yahoo.com,aik_mik@yahoo.com, athmarjaffer@yahoo.com

Received May $27^{\text {th }}, 2010$; revised June $24^{\text {th }}, 2010$; accepted June $27^{\text {th }}, 2010$.

\begin{abstract}
Wastewater reuse is a useful tool in minimizing the amount of wastewater in the environment. Therefore, evaluation of the suitability of Al-Rustamiyah WWTP municipal treated wastewater for irrigation was made according to its composition and the international irrigation water quality standards. In addition, to classify water quality and to evaluate its suitability for irrigation purposes, Sodium Adsorption Ratio (SAR), Soluble Sodium Percentage (SSP) and Residual Sodium Carbonate (RSC) were calculated following standard equations and found experimentally as (2.11), (35.67) and (-12.75) respectively. Plotting the values of conductivity (EC) and sodium absorption ratio (SAR) on the US salinity diagram illustrated that most of the samples fall in the field of C3-S1, indicating high salinity and low sodium water which can be used for irrigation on almost all types of soil without danger of exchangeable sodium. Furthermore, the data indicate slight to moderate degree of restriction on the use of this treated wastewater in irrigation due to chloride hazard. RSC value is negative at all sampling sites, indicating that there is no complete precipitation of calcium and magnesium. Overall, the treated wastewater can be classified with few exceptions as suitable for irrigation use.
\end{abstract}

Keywords: Wastewater Reuse, Irrigation, Sodium Adsorption Ratio (SAR), Residual Sodium Carbonate (RSC), Soluble Sodium Percentage (SSP)

\section{Introduction}

In many arid and semi-arid countries water is becoming an increasingly scarce resource and planners are forced to consider any sources of water which might be used economically and effectively to promote further development. Thus, the availability of good-quality water for irrigation is threatened in many places [1] and irrigated agriculture faces the challenge of using less water, in many cases of poorer quality, to irrigate lands that provide food for an expanding population.

The irrigation water needs can be met by using the available water more efficiently, but in many cases it will prove necessary to make increased use of municipal wastewaters [2]. The use of wastewater in agriculture has potential for both positive and negative environmental impacts [3]; with careful planning and management the use of wastewater in agriculture can be beneficial to the environment. However, the direct and indirect use of untreated wastewater in irrigated agriculture is increasing as a result of increasing global water scarcity, inadequate and inappropriate wastewater treatment and disposal, increased food insecurity and escalating fertilizer costs [4-6]. Consequently, the reuse of wastewater for agriculture is highly encouraged $[7,8]$ and it is a common practice for many reasons, not least of which is nutrient value and environmental protection $[1,9]$. Irrigation with treated municipal wastewater is considered an environmentally sound wastewater disposal practice compared to its direct disposal to the surface or ground water bodies $[3,8]$.

Wastewater is a valuable source of plant nutrients and organic matter [10]. Nevertheless, it may contain undesirable chemical constituents and pathogens that pose negative environmental and health impacts [11]. At the same time, a number of risk factors have been identified in wastewater reuse, some of them are short term (e.g., microbial pathogens) whereas others have longer-term impacts that increase with the continued use of recycled water (e.g., salinity effects on soil). So, many guidelines have been developed to give a quality criteria and guidance on how treated wastewater (effluents) should be reused for irrigation purposes [12,13]. 
The amount of collected and treated wastewater is likely to increase significantly with population growth, rapid urbanization, and improvement of sanitation service coverage [14-16]. Hence, the use of treated wastewater in agriculture is one of the strategies adopted for increasing water supply in arid and semi arid countries $[17,18]$. Wastewater also has been used in agriculture for decades in many countries like India [15], Nepal [19], China [20], Spain [21] and Italy [22]. Under the conditions of increased freshwater scarcity at Arabian countries like Saudi-Arabia [17], Kuwait [23,24] and Jordan $[25,26]$, the reuse of wastewater in agriculture is receiving great attention and increased recognition as a potential water source.

It is generally accepted that wastewater use in agriculture is justified on agronomic and economic grounds but care must be taken to minimize adverse health and environmental impacts. However, in Iraq such usage of treated or untreated wastewater has not been widely investigated and evaluated. In view of these facts, the present study was undertaken to characterize the secondary treated wastewater produced from Al-Rustamiyah WWTP and to evaluate its suitability for irrigation purposes as non-conventional water resources.

\section{Materials and Methods}

\subsection{The Study Area}

The Iraqi capital, Baghdad, has the highest level of sanitation provision with about $80 \%$ of the population connected to sewer conveying sewage to treatment facilities. It is located in the Mesopotamian alluvial plain between latitudes $33^{\circ} 14^{\prime}-33^{\circ} 25^{\prime} \mathrm{N}$ and longitudes $44^{\circ} 31^{\prime}-44^{\circ} 17^{\prime}$ ' E. The general altitude ranges between 30.5 and $34.85 \mathrm{~m}$ a.s.1. Tigris River divides the city into a right (Karkh) and left (Risafa) sections (Figure 1). The area is characterized by arid to semi arid climate with dry hot summers and cold winters; the mean annual rainfall is about 151.8 $\mathrm{mm}$ [27].

The sewerage network that was established between 1960 and 1980 worked on the basis of the separate system, but a combined system has been adopted since 1980 . In general, the wastewater quantities generated within the urban and rural areas of the mayoralty of Baghdad are estimated at 1,426,013 and 2,354 cubic meters per day respectively. However, the capacity of all wastewater treatment plants in the mayoralty of Baghdad was estimated at 789, 200 cubic meters per day, in which it represents as $55 \%$ of the total capacity of wastewater. The secondary treated wastewater effluent for Iraqi (WWTP) was designed to produce an average of final effluent quality of biological oxygen demand (BOD) and total suspended solids (TSS) as 20 and $30 \mathrm{mg} / \mathrm{L}$, respectively to

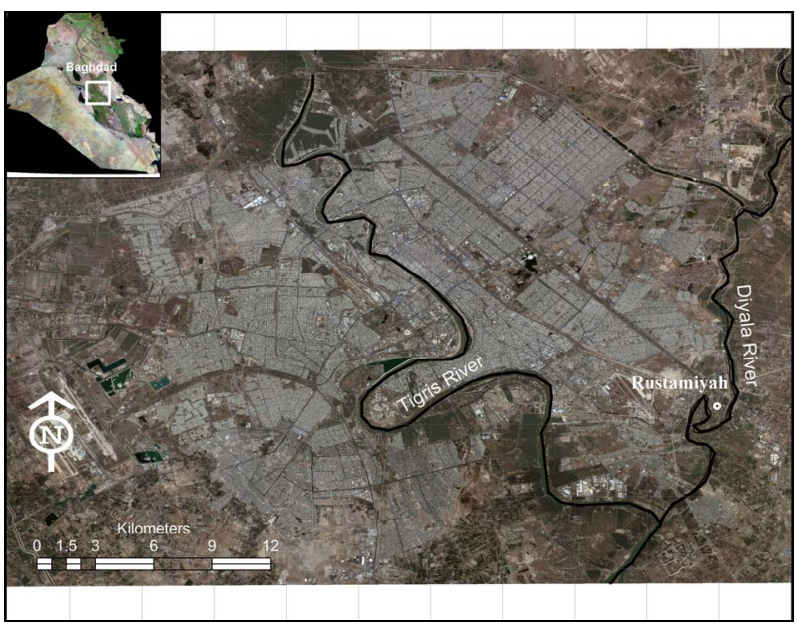

Figure 1. Base map of Baghdad city.

meet the Iraqi National Standards set by the Regulation 25 of 1967 . It reported that each day 500,000 cubic meters of raw sewage are discharged into Iraqi waterways [3].

In the Iraqi wastewater treatment plants, the existing pumping stations are also inefficient because of the lack of proper operation and maintenance and unavailability of spare parts. Despite this, most of the treated wastewater in the area under study (Baghdad City) was mixed with freshwater from the Diyala River and used downstream for unrestricted irrigation. Thus around 50\% of the total treated wastewater generated could be reused [3].

\subsection{Sampling and Analysis}

Treated wastewater samples from Al-Rustamiyah WWTP were bimonthly collected during January 2009 to December 2009 in stopper fitted polyethylene bottles that prewashed with dilute hydrochloric acid and then rinsed several times with the effluent sample before filling them to the required capacity. These samples were stored at a temperature below $4^{\circ} \mathrm{C}$ prior to analysis in the laboratory. Procedures followed for analysis have been in accordance with the Standard methods for examination of water and wastewater [28]. The calibration for different chemical constituents was done by preparing low-level standard solutions using AR-grade chemicals and was periodically repeated to check the accuracy. Calcium $\left(\mathrm{Ca}^{2+}\right)$ and Magnesium $\left(\mathrm{Mg}^{2+}\right)$ were determined titrimetrically using standard EDTA, while Chloride $\left(\mathrm{Cl}^{-}\right)$was determined by standard $\mathrm{AgNO}_{3}$ titration. Carbonate $\left(\mathrm{CO}_{3}{ }^{2-}\right)$ and Bicarbonate $\left(\mathrm{HCO}_{3}{ }^{-}\right)$were determined by titration with $\mathrm{HCl}$. Sodium $\left(\mathrm{Na}^{+}\right)$and Potassium $\left(\mathrm{K}^{+}\right)$ were measured by flame photometry and Sulphate $\left(\mathrm{SO}_{4}{ }^{2-}\right)$ by spectrophotometer turbidimetry. Total Suspended Solid (TSS) and Total Dissolved Solid (TDS) were de- 
termined by gravimetric method (dried at $103^{\circ} \mathrm{C}$ ). Biological Oxygen Demand (BOD) was determined by the 5 Day BOD test while Chemical Oxygen Demand (COD) was determined in the laboratory by the standard Open Reflux Method. Other tests such as Conductivity (EC) and $\mathrm{pH}$ were directly measured in situ using portable measuring devices (HANNA instruments, HI 9811, portable pH-EC-TDS METER, Italy). Note that before each measurement, the $\mathrm{pH}$ meter was calibrated with reference buffer solution. Each analysis was carried out in triplicate and then the mean value was taken.

\subsection{Indicators of Water Quality for Irrigation}

Important irrigation water quality parameters include a number of specific properties of water relevant in relation to the yield and quality of crops, maintenance of soil productivity and protection of the environment. These parameters mainly consist of certain physical and chemical characteristics of water that are used in the evaluation of agricultural water quality. Numerous water quality guidelines have been developed by many researchers for using water in irrigation under different condition [29-32]. However, the classification of US Salinity Laboratory (USSL) is used most commonly. Parameters such as EC, pH, Sodium Adsorption Ratio (SAR), adjusted SAR (adj SAR) and the Exchangeable Sodium Percentage (ESP), Soluble Sodium Percentage (SSP) and Residual Sodium Carbonate (RSC) were used to assess the suitability of water for irrigation purposes. The criteria used to evaluate quality of wastewater for use in agriculture are listed in Table $\mathbf{1}$.

\section{Results and Discussion}

Descriptive statistics for all characteristics are presented in Table 2. An explanation of the observed characteristics follows in the following sections.

\subsection{Hydrogen Ion Activity (pH)}

The values of $\mathrm{pH}$ varied from 6.87 to 8.40 with an average value of 7.70 , which indicates that the treated municipal wastewater is slightly alkaline in nature. The normal $\mathrm{pH}$ range for irrigation water is from 6.5 to 8.4. Irrigation water with a $\mathrm{pH}$ outside the normal range may cause a nutritional imbalance or may contain a toxic ion $[32,33]$.

\subsection{Salinity Hazard}

Electrical conductivity (EC) is the most important parameter in determining the suitability of water for irrigation use and it is a good measurement of salinity hazard to crop as it reflects the TDS in wastewater. The most important negative effect on the environment caused by agricultural wastewater is the increases in soil salinity, which if not controlled, can decrease productivity in long term [3]. EC values of experimental samples varied from 1910 to $2120 \mu \mathrm{S} / \mathrm{cm}$ (mean value $=1949.78 \mu \mathrm{S} / \mathrm{cm})$ while TDS values varied from 1164 to $1350 \mathrm{mg} / \mathrm{L}$ (mean value $=1234.6 \mathrm{mg} / \mathrm{L}$ ) indicating slight to moderate degree of restriction on the use of this wastewater in irrigation due to salt build-up in soils and its adverse effects on plant growth [32]. Furthermore, the results indicted also that this type of water can be used on the soils with restricted drainage. Special salinity control management with selection of good salt tolerant plants is required. However, irrigation water with conductivity in the range of $750-2250 \mu \mathrm{S} / \mathrm{cm}$ is permissible for irrigation and widely used. Satisfactory crop growth is obtained under good management and favorable drainage conditions but saline conditions will develop if leaching and drainage are inadequate [30]. It is clear that irrigation using saline water can add salt concentration to the soils and a problem may be occurred due to the increase in concentration that is harmful to the crop or landscape. Therefore, it is necessary to combine the use of wastewater with practices to control salinization, such as soil washing and appropriate soil drainage [3]. The primary effect of high EC reduces the osmotic activity of plants and thus interferes with the absorption of water and nutrients from the soil [34].

\subsection{Sodium Hazard}

Sodium content is the most troublesome of the major constituents and an important factor in irrigation water quality evaluation. Excessive sodium leads to development of an alkaline soil that can cause soil physical problems and reducing soil permeability [35]. Furthermore, irrigation water containing large amounts of sodium is of special concern due to absorbed sodium by plant roots which is transported to leaves where it can accumulate and cause injury [36]. However, there is a restriction in use of overhead sprinklers method with water contained a high level of sodium salts because these salts can be absorbed directly by plant leaves and will produce harmful effects.

The water can be used for irrigation when the concentration of sodium is about $8.0 \mathrm{meq} / \mathrm{L}(184.0 \mathrm{mg} / \mathrm{L})$ [37]. Sodium concentrations in the samples varied from 123.60 to $221.0 \mathrm{mg} / \mathrm{L}$ (mean value $=171.11$ ), indicating slight to moderate to high degree of restriction for sensitive crops on the use of this wastewater in irrigation [32]. Sensitive crops include deciduous fruits, nuts, citrus, avocados and beans, but there are many others. In the case of tree crops, sodium in the leaf tissue in excess of $0.25-0.50$ percent (dry weight) is often associated with sodium toxicity [32]. 
Table 1. Water quality classes for agricultural irrigation.

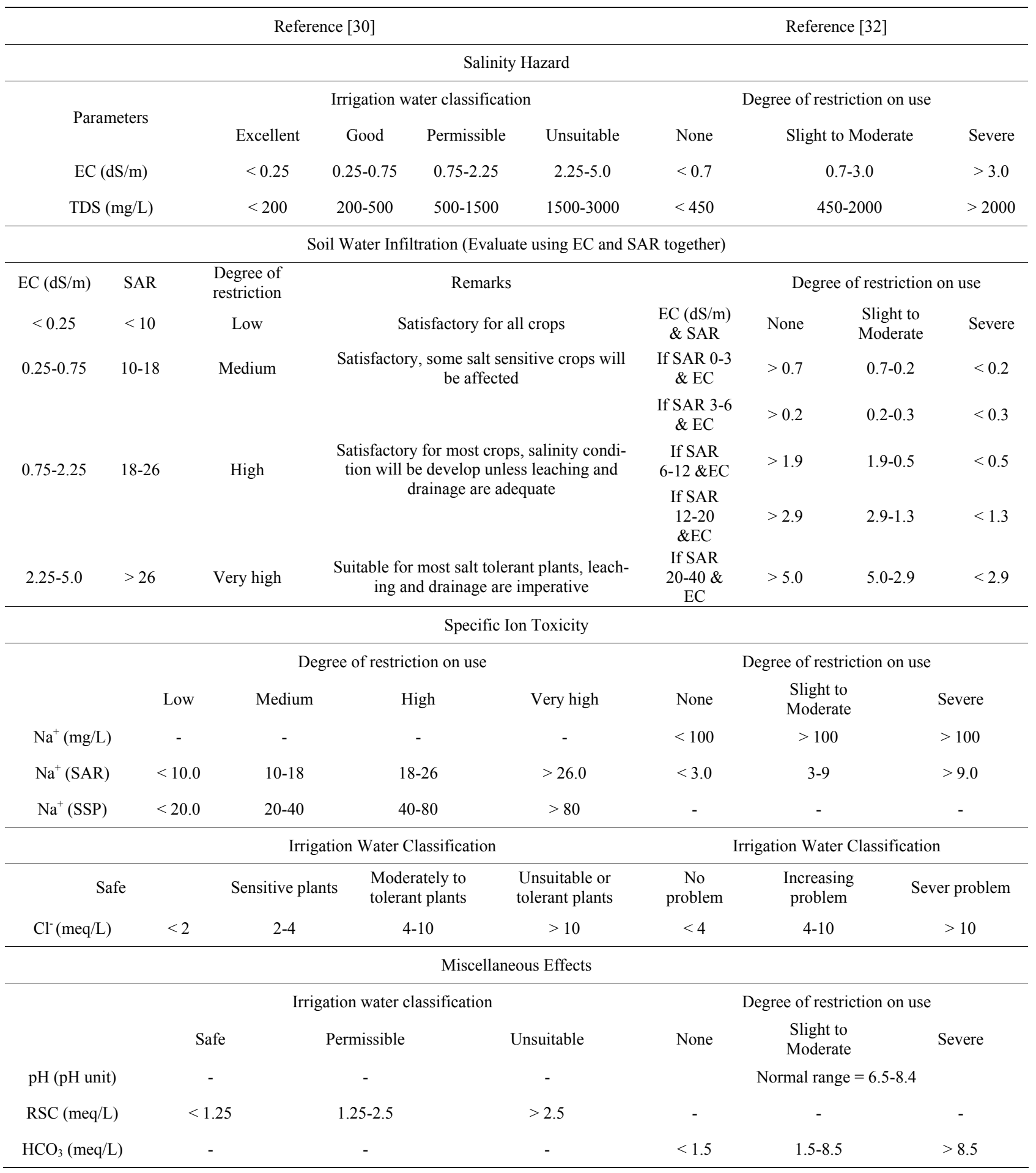

Sodium hazard is usually expressed in terms of Sodium Adsorption Ratio (SAR) and it can be calculated from the ratio of sodium to calcium and magnesium. SAR is an important parameter for the determination of the suitability of irrigation water because it is responsible for the sodium hazard [38], since it is more closely related to exchangeable sodium percentages in the soil than the simpler sodium percentage [39]. Sodium replacing adsorbed calcium and magnesium is a hazard as it causes damage to the soil structure. It becomes compact and im- 
Table 2. Summary statistics of the analytical data.

\begin{tabular}{ccccc}
\hline Characteristics & Min. & Max. & Mean & $\begin{array}{c}\text { Standard } \\
\text { deviation }\end{array}$ \\
\hline $\mathrm{pH}($ standard units $)$ & 6.87 & 8.40 & 7.70 & \pm 0.39 \\
$\mathrm{EC}(\mu \mathrm{S} / \mathrm{cm})$ & 1910.0 & 2120.0 & 1949.78 & \pm 48.75 \\
$\mathrm{TDS}(\mathrm{mg} / \mathrm{L})$ & 1164.0 & 1350.0 & 1234.60 & \pm 63.09 \\
$\mathrm{TSS}(\mathrm{mgL})$ & 10.00 & 112.00 & 49.30 & \pm 27.67 \\
$\mathrm{Ca}^{2+}(\mathrm{mg} / \mathrm{L})$ & 99.70 & 290.18 & 157.54 & \pm 40.34 \\
$\mathrm{Mg}^{2+}(\mathrm{mg} / \mathrm{L})$ & 33.00 & 149.20 & 69.02 & \pm 29.60 \\
$\mathrm{~K}^{+}(\mathrm{mg} / \mathrm{L})$ & 9.00 & 26.90 & 16.38 & \pm 5.19 \\
$\mathrm{Na}^{+}(\mathrm{mg} / \mathrm{L})$ & 123.60 & 221.00 & 171.11 & \pm 22.28 \\
$\mathrm{HCO}_{3}{ }^{-}(\mathrm{mg} / \mathrm{L})$ & 24.88 & 73.80 & 45.16 & \pm 11.07 \\
$\mathrm{CO}_{3}{ }^{2-}(\mathrm{mg} / \mathrm{L})$ & 0.00 & 12.30 & 9.80 & \pm 3.44 \\
$\mathrm{Cl}^{-}(\mathrm{mg} / \mathrm{L})$ & 171.44 & 254.92 & 205.25 & \pm 21.67 \\
$\mathrm{SO}_{4}{ }^{2-}(\mathrm{mg} / \mathrm{L})$ & 199.00 & 358.00 & 245.09 & \pm 43.76 \\
$\mathrm{BOD}^{(\mathrm{mg} / \mathrm{L})}$ & 12.00 & 66.00 & 26.36 & \pm 10.85 \\
$\mathrm{COD}^{(\mathrm{mg} / \mathrm{L})}$ & 36.00 & 80.00 & 53.10 & \pm 13.90 \\
\hline
\end{tabular}

pervious. It has been calculated as follows:

$$
\mathrm{SAR}=\frac{\mathrm{Na}^{+}}{\sqrt{\frac{\mathrm{Ca}^{2+}+\mathrm{Mg}^{2+}}{2}}}
$$

where: $\mathrm{Na}^{+}, \mathrm{Ca}^{2+}$ and $\mathrm{Mg}^{2+}$ are in meq/L.

For waters containing significant amounts of bicarbonate, Bower and Maasland [40] proposed a modification in the old SAR procedure to include changes in soil water composition that are expected to result due to dissolution/precipitation of lime in the soil upon irrigation. Therefore, the adjusted sodium adsorption ratio (adj SAR) is sometimes used [32], and it is an SAR value corrected to account for the removal of $\mathrm{Ca}^{2+}$ and $\mathrm{Mg}^{2+}$ by their precipitation with $\mathrm{CO}_{3}{ }^{2-}$ and $\mathrm{HCO}_{3}{ }^{-}$ions in the water added [37]. It can be calculated as in reference [41] by using the following formula:

$$
\text { adj SAR }=\text { SAR }[1+(8.4-\text { pHc })]
$$

where 8.4 is the approximate of a nonsodic saline soil in equilibrium with $\mathrm{CaCO}_{3}$ and is substituted for the $\mathrm{pH}$ of water. This substitution reflects the high buffering capacity of calcareous soils. $\mathrm{pHc}$ is defined by:

$$
\mathrm{pHc}=\left(\mathrm{pK}_{2}+\mathrm{pK}_{\mathrm{c}}\right)+\mathrm{p}\left(\mathrm{Ca}^{2+}+\mathrm{Mg}^{2+}\right)+\mathrm{pAlk}
$$

where $p$ refers to the negative logarithm, $\mathrm{K}_{2}$ is the second dissociation equilibrium constant of carbonic acid, $\mathrm{K}_{\mathrm{c}}$ is solubility equilibrium constant for calcite. Concentrations of $\mathrm{Ca}^{2+}, \mathrm{Mg}^{2+}, \mathrm{CO}_{3}{ }^{2-}$ and $\mathrm{HCO}_{3}^{-}$in meq/L.
The pHc can be calculated using the standard table given by reference [41] which related to the concentration values from water analysis. This concept has been found very useful for predicting the effect of sodium hazard of irrigation water on soil properties. Values of $\mathrm{pHc}$ above 8.4 indicate tendency to dissolve lime from soil through which the water moves; values below 8.4 indicate tendency to precipitate lime from waters applied [32].

A new adj SAR method [42] is derived which adjusts the calcium concentration of the irrigation water to the expected equilibrium value and includes the effects of carbon dioxide $\mathrm{CO}_{2}$, carbonate $\left(\mathrm{HCO}_{3}^{-}\right)$and of salinity (EC) upon the calcium originally present in the applied water but now a part of the soil water. The new adjusted SAR is termed widely as adj RNa, and the equation is as follows:

$$
\operatorname{adj} \mathrm{RNa}=\frac{\mathrm{Na}^{+}}{\sqrt{\frac{\mathrm{Ca}_{\mathrm{x}}{ }^{2+}+\mathrm{Mg}^{2+}}{2}}}
$$

where $\mathrm{Ca}_{\mathrm{x}}{ }^{2+}$, a modified calcium concentration value in $\mathrm{meq} / \mathrm{L}$ expected to remain in near surface soil water following irrigation with water of given $\mathrm{HCO}_{3}{ }^{-} / \mathrm{Ca}^{2+}$ ratio and EC available from the standard Tables [32].

The SAR value of the treated wastewater ranges from 1.43 to 3.19 (mean $=2.11$ ), while adj SAR and adj $\mathrm{RNa}$ values range from 2.35 to 4.40 (mean $=3.12)$ and from 1.52 to $3.03($ mean $=2.03)$ respectively $($ Table 3$)$. The comparison between SAR, adj SAR and adj RNa values and their standard values reflects water is suitable for irrigation.

Total salt concentration of irrigation waters should not be used as single criteria to prevent it in irrigation use.

Table 3. Calculated irrigation quality characteristics.

\begin{tabular}{ccccc}
\hline Characteristics & Min. & Max. & Mean & $\begin{array}{c}\text { Standard } \\
\text { deviation }\end{array}$ \\
\hline SAR & 1.43 & 3.19 & 2.11 & \pm 0.43 \\
adj SAR & 2.35 & 4.40 & 3.12 & \pm 0.58 \\
adj RNa & 1.52 & 3.03 & 2.03 & \pm 0.36 \\
SSP & 21.38 & 50.82 & 35.67 & \pm 6.75 \\
ESP (SAR) & 0.84 & 3.34 & 1.82 & \pm 0.61 \\
ESP (adj SAR) & 2.16 & 4.97 & 3.25 & \pm 0.80 \\
ESP (SAR RNa) & 1.00 & 3.12 & 1.70 & \pm 0.51 \\
pHc & 7.63 & 8.14 & 7.90 & \pm 0.3 \\
RSC & -25.91 & -7.07 & -12.75 & \pm 4.002 \\
$\mathrm{Mg}^{2+}$ Hazards & 7.97 & 56.53 & 39.86 & \pm 10.44 \\
\hline
\end{tabular}


Even water with high salt concentration can still be used for irrigation without endangering soil productivity. High sodium content common to recycle water can cause deflocculating (breakdown) of soil clay particles, severely reducing soil aeration and water infiltration and percolation. In other words, soil permeability is reduced by irrigation with water high in sodium $[35,43]$. It is therefore, the best measure of a water likely effect on soil permeability is the waters SAR considered together with its EC. In this respect, the US salinity diagram (Figure 2) which is based on the integrated effect of EC (salinity hazard) and SAR (alkalinity hazard), has been used to assess the water suitability for irrigation [30]. When the analytical data of EC and SAR plotted on the US salinity diagram, it is illustrated that most of the treated wastewater samples fall in the class of C3-S1 indicating high salinity with low sodium water, which can be used for irrigation on almost all types of soil, with only a minimum risk of exchangeable sodium. This type of water can be suitable for plants having good salt tolerance but restricts its suitability for irrigation, especially in soils with restricted drainage $[30,44]$. Figure 3 shows the positive correlation between EC and SAR with a correlation coefficient $\left(R^{2}\right)$ $=0.193$. The lower values of $R^{2}$ show that there is a higher variation in the EC values.

\subsection{Soluble Sodium Percentage (SSP)}

It is also used to evaluate sodium hazard. The Soluble Sodium Percentage (SSP) was calculated as in reference [29] by the following equation:

$$
\mathrm{SSP}=\frac{\left(\mathrm{Na}^{+}\right) \times 100}{\mathrm{Ca}^{2+}+\mathrm{Mg}^{2+}+\mathrm{Na}^{+}+\mathrm{K}^{+}}
$$

where all the ions are expressed in meq/L.

Water with SSP greater than 60 percent may result in sodium accumulations that will cause a breakdown of the soil's physical properties [45]. The calculated values of SSP varied from $21.38 \%$ to $50.82 \%$ (mean value $=$ $35.67 \%$ ) indicating moderate degree of restriction on the use of this wastewater in irrigation. When the concentration of sodium ion is high in irrigation water, $\mathrm{Na}^{+}$ion tends to be absorbed by clay particles, displacing $\mathrm{Mg}^{2+}$ and $\mathrm{Ca}^{2+}$ ions. This exchange process in soil reduces the permeability and eventually results in soil with poor internal drainage [32]. Figure 4 shows the positive correlation between SSP and SAR with a coefficient of 0.786 .

Irrigation with waters that have high concentrations of $\mathrm{Na}^{+}$ion relative to divalent cations may cause an accumulation of exchangeable $\mathrm{Na}^{+}$on soil colloids. Continued uses of alkaline waters for irrigation in a closed system may have adverse effects on soil physical properties $[46,47]$, deteriorate the soil and water resources of the region and affect the sustainability of crop production in the long run.

It is reported that salinity and sodicity are the principal water quality concerns in irrigated areas receiving such water [48]. Saline-sodic irrigation water, coupled with limited rainfall and high evaporation, may increase soil sodicity significantly. In general, when sodium is an important component of the salts, there can be a significant amount of adsorbed sodium making the soil sodic [31].

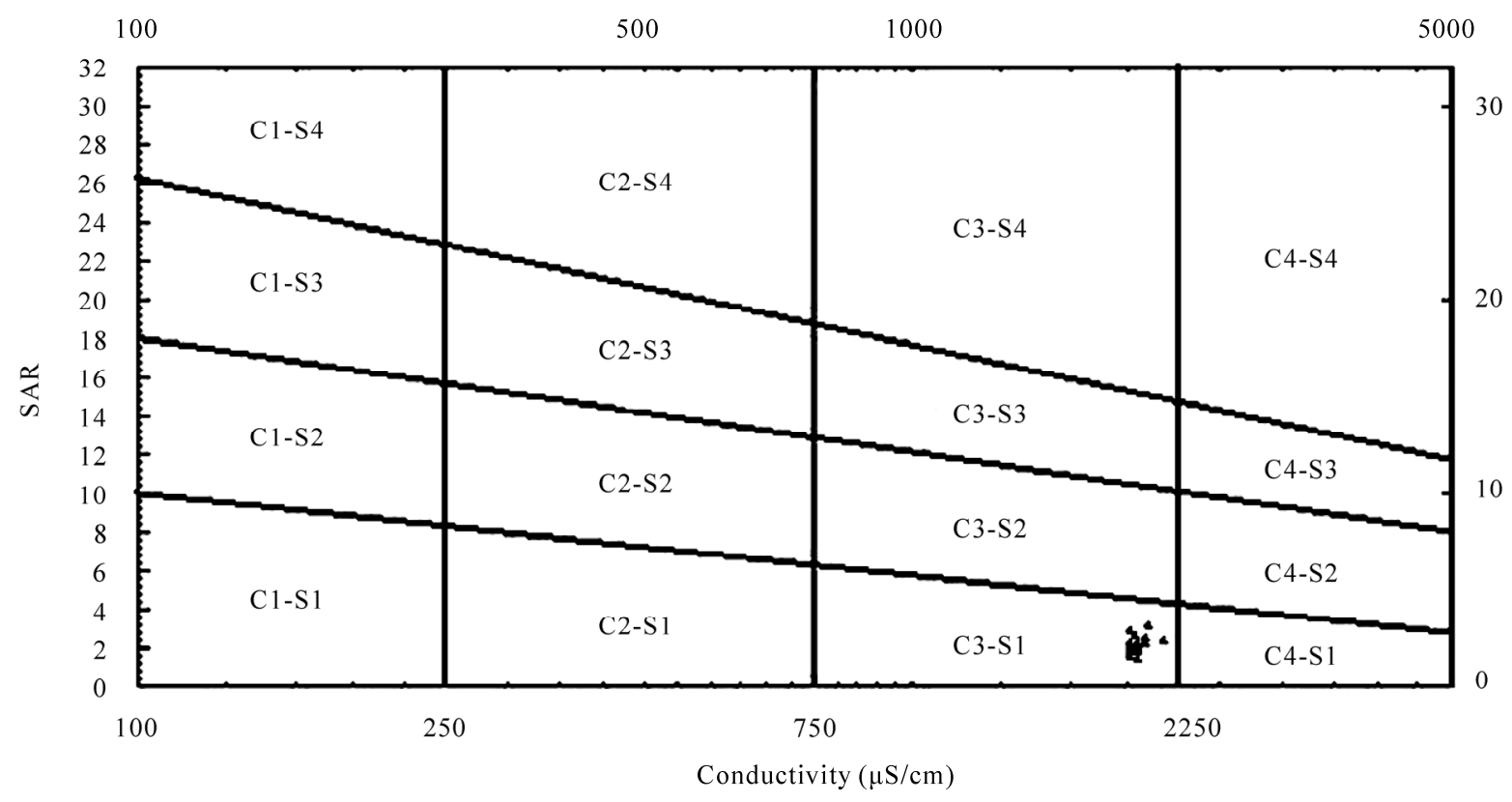

Figure 2. Rating of water samples in relation to salinity and sodium hazard. 


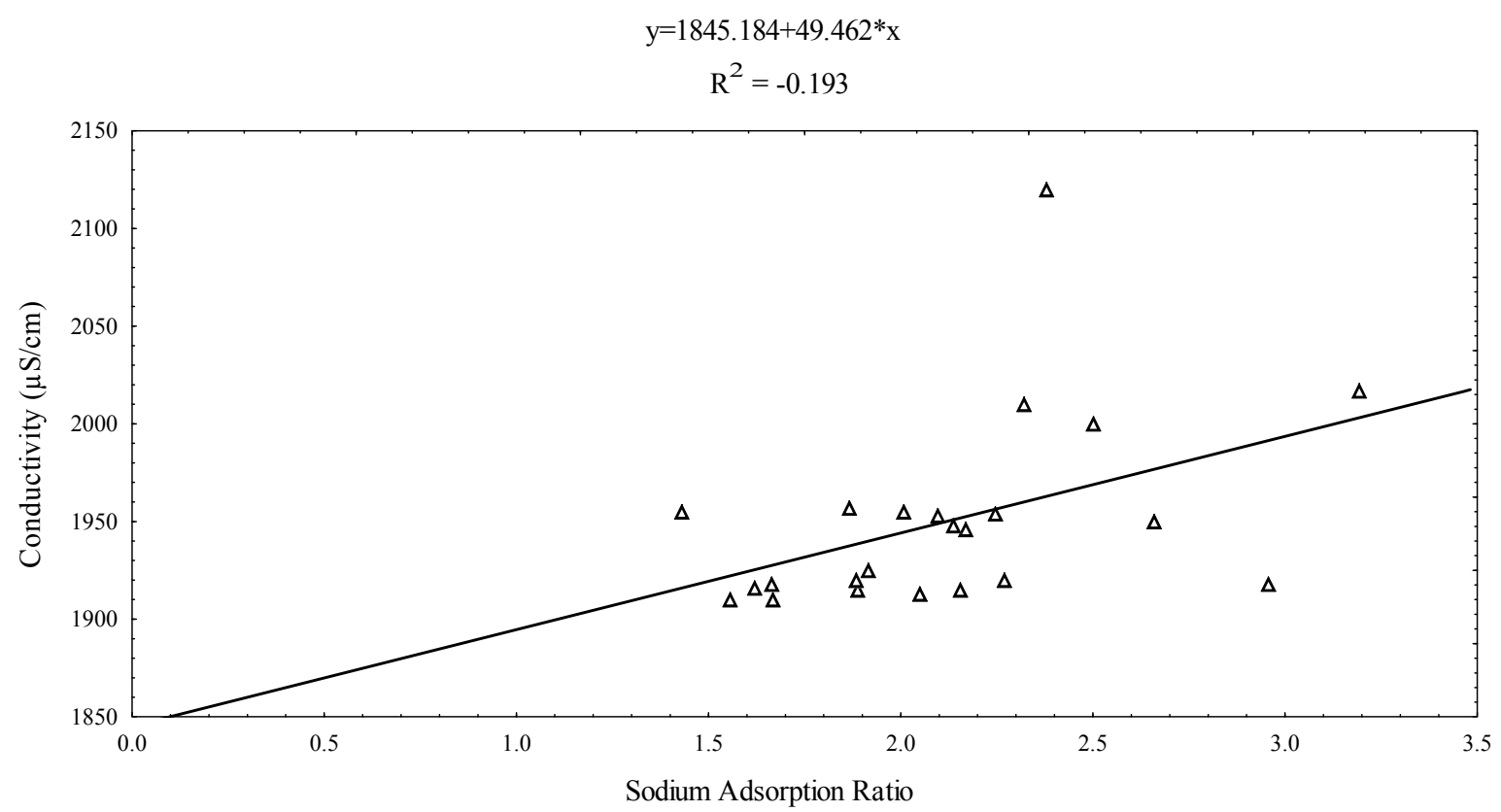

Figure 3. Correlation between sodium adsorption ratio and conductivity.

$$
\begin{gathered}
y=6.41+13.835 * x \\
R^{2}=0.786
\end{gathered}
$$

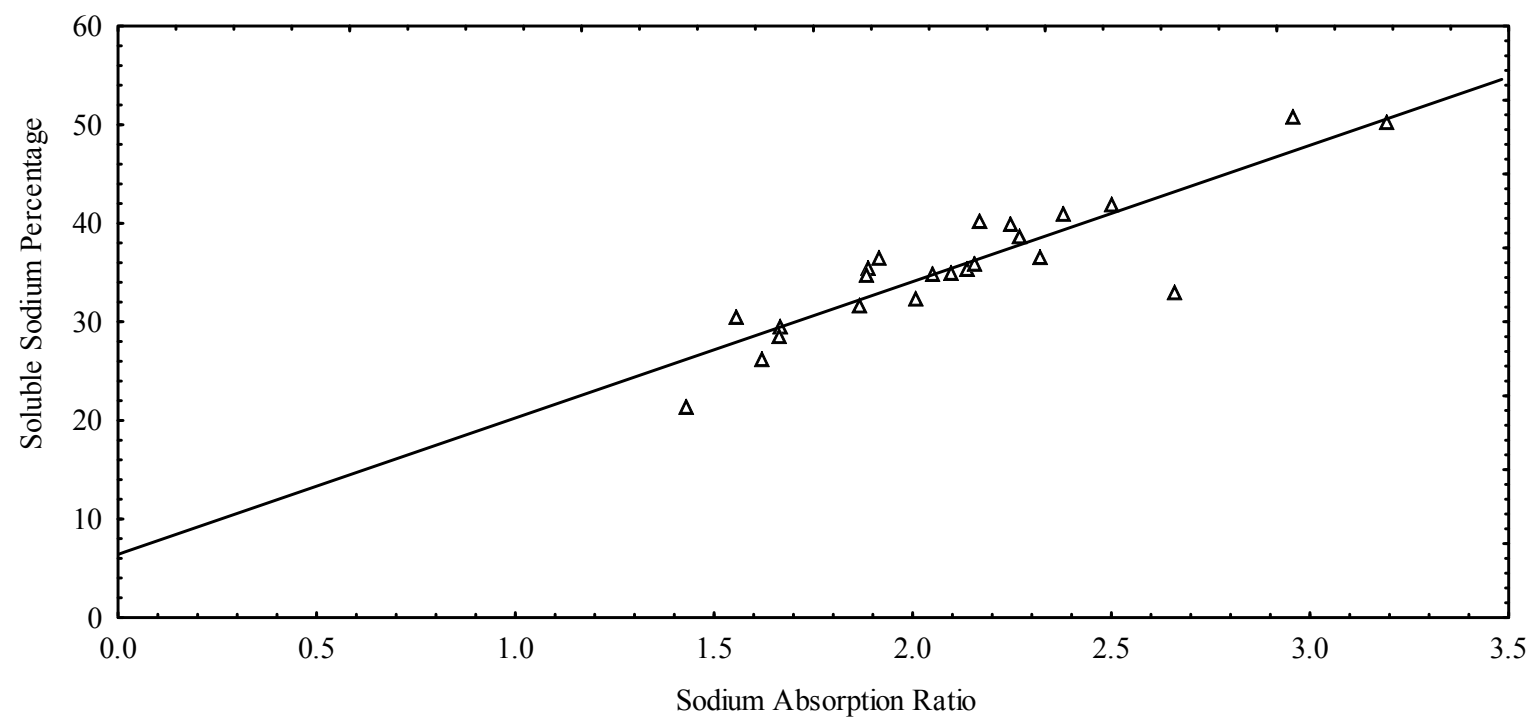

Figure 4. Correlation between sodium adsorption ratio and percentage sodium.

The ratio of the exchangeable $\mathrm{Na}^{+}$to total exchangeable cations (Exchangeable Sodium Percentage, ESP) is a good indicator for soil structure deterioration. Although, the ESP of $10-15 \%$ is generally accepted as a critical level, an ESP of $25 \%$ may have little effect on soil structure in a sandy soil, whereas an ESP of 5\% is considered high particularly in soils containing 2:1 clay minerals like montmorillonite [49]. The ESP of soils can be predicted quite well from the following the empirical relationship [30]:

$$
\mathrm{ESP}=\frac{100(-0.0126+0.01475 \mathrm{SAR})}{1+(-0.0126+0.01475 \mathrm{SAR})}
$$

The expected ESP for the experimental data would be 
in range of 0.84-3.34 SAR, 2.16-4.97 adj SAR and 1.0-3.12 SAR RNa as shown in Table 3. The ESP predicted from adj SAR of treated wastewater was higher than those predicted from SAR and SAR RNa.

\subsection{Chloride Hazard}

The most common toxicity is from chloride $\left(\mathrm{Cl}^{-}\right)$in the irrigation water. $\mathrm{Cl}^{-}$is not adsorbed or held back by soils, therefore it moves readily with the soil-water, is taken up by the crop, moves in the transpiration stream, and accumulates in the leaves. If the $\mathrm{Cl}^{-}$concentration in the leaves exceeds the tolerance of the crop, injury symptoms develop such as leaf burn or drying of leaf tissue. Normally, plant injury occurs first at the leaf tips (which is common for chloride toxicity), and progresses from the tip back along the edges as severity increases. Excessive necrosis (dead tissue) is often accompanied by early leaf drop or defoliation [33]. The obtained $\mathrm{Cl}^{-}$ion concentration of the samples varied from 171.44 to $254.92 \mathrm{mg} / \mathrm{L}$ (mean value $=205.25)$ representing slight to moderate degree of restriction on the use of this wastewater in irrigation [32]. While, according to USSL classification of irrigation water, the effluent samples can be used for moderately tolerant plants [30]. Chemical analysis of plant tissue is commonly used to confirm chloride toxicity. The part of the plant generally used for analysis varies with the crop, depending upon which of the available interpretative values is being followed. However, for irrigated areas, the chloride uptake depends not only on the water quality but also on the soil chloride, controlled by the amount of leaching that has taken place and the ability of the crop to exclude chloride. Crop tolerances to chloride are not nearly so well documented as crop tolerances to salinity [32]. On the other hand, significant correlation was found between $\mathrm{Na}^{+}$and $\mathrm{Cl}^{-}$of wastewater $\left(R^{2}=0.60\right)$, suggesting that the common source of these ions is salt dissolution. The possible sources of these ions were anthropogenic and natural.

\subsection{Magnesium Hazard}

Generally, $\mathrm{Ca}^{2+}$ and $\mathrm{Mg}^{2+}$ maintain a state of equilibrium in most waters. Both $\mathrm{Ca}^{2+}$ and $\mathrm{Mg}^{2+}$ ions are associated soil aggregation and friability, but they are also essential plant nutrients. High concentration of $\mathrm{Ca}^{2+}$ and $\mathrm{Mg}^{2+}$ ions in irrigation water can increase soil $\mathrm{pH}$, resulting in reducing of the availability of phosphorous [23]. Water containing $\mathrm{Ca}^{2+}$ and $\mathrm{Mg}^{2+}$ higher than $10 \mathrm{meq} / \mathrm{L}(200 \mathrm{mg} / \mathrm{L})$ cannot be used in agriculture [50]. The observed results show that $60 \%$ of the samples have exceeded $200 \mathrm{mg} / \mathrm{L}$. High correlation was found between $\mathrm{Ca}^{2+}$ and $\mathrm{Mg}^{2+}$ of wastewater $\left(R^{2}=0.68\right)$, suggesting that the common source of these ions is carbonate dissolution.
Another indicator that can be used to specify the magnesium hazard $(\mathrm{MH})$ is proposed by reference [51] for irrigation water as in the following formula:

$$
\mathrm{MH}=\frac{\mathrm{Mg}^{2+}}{\mathrm{Ca}^{2+}+\mathrm{Mg}^{2+}} \times 100
$$

where, $\mathrm{Ca}^{2+}$ and $\mathrm{Mg}^{2+}$ ions are expressed in meq/L.

If the value of MH is less than 50, then the water is safe and suitable for irrigation [50]. From the calculated value (Table 3), the MH values range between 7.97-56.53\%, $($ mean $=39.86)$ and the treated wastewater can be classified with few exception as suitable for irrigation use.

\subsection{Residual Sodium Carbonate (RSC)}

The excess sum of $\mathrm{CO}_{3}{ }^{2-}$ and $\mathrm{HCO}_{3}{ }^{-}$in wastewater over the sum of $\mathrm{Ca}^{2+}$ and $\mathrm{Mg}^{2+}$ influences the unsuitability of wastewater for irrigation. In water having high concentration of $\mathrm{CO}_{3}{ }^{2-}$ and $\mathrm{HCO}_{3}{ }^{-}$, there is tendency for $\mathrm{Ca}^{2+}$ and $\mathrm{Mg}^{2+}$ to precipitate as carbonates. To qualify this effect, an experimental parameter termed as RSC [29] was used. It can be calculated as follows:

$$
\mathrm{RSC}=\left(\mathrm{CO}_{3}{ }^{2-}+\mathrm{HCO}_{3}^{-}\right)-\left(\mathrm{Ca}^{2+}+\mathrm{Mg}^{2+}\right)
$$

All ion concentrations are reported in meq/l.

The water with high RSC has high $\mathrm{pH}$ and land irrigated by such waters becomes infertile owing to deposition of sodium carbonate as known from the black colour of the soil [29]. According to the USSL [30], RSC value less than $1.25 \mathrm{meq} / \mathrm{L}$ is safe for irrigation, a value between 1.25 and $2.5 \mathrm{meq} / \mathrm{L}$ is of permissible quality and a value more than $2.5 \mathrm{meq} / \mathrm{L}$ is unsuitable for irrigation. The calculated RSC value $(-12.75)$ show that all samples have RSC less than zero and are good suitable for irrigation purposes.

\subsection{Other Related Characteristics}

The oxygen demand arises from the biochemical degradation of organic materials, the oxidation of inorganic material such as sulphides and ferrous and possibly the oxidation of reduced from of nitrogen [28]. The BOD, COD and TSS values in the present study varied from 12 to $66 \mathrm{mg} / \mathrm{L}, 36$ to $80 \mathrm{mg} / \mathrm{L}$ and 10 to $112 \mathrm{mg} / \mathrm{L}$, respectively. With few exceptions, the treated wastewater in this study area displayed higher values of BOD, COD and TSS. Calculated results highlight that the final effluent produced from Al-Rustamiyah WWTP did not meet the Iraqi National Standards set by Regulation 25 of 1967. Ultimately, reconsideration of the WWTPs system and completed environmental impact assessment are needed.

\section{Conclusions}

Interpretation of physical and chemical analysis revealed 
that the treated wastewater of Baghdad City is slightly alkaline in nature. The US salinity diagram illustrates that most of the treated wastewater samples fall in the field of C3S1, indicating high salinity and low sodium water, which can be used for irrigation on almost all types of soil without danger of exchangeable sodium. Therefore, the sustainable use of treated wastewater in agriculture can be beneficial to the environment in such a way that minimizes the side effects on the quality of downstream water resources, but it requires the control of soil salinity at the field level.

Based on these results that proper management of wastewater irrigation and periodic monitoring of quality parameters are required to ensure successful, safe and long term reuse of wastewater for irrigation. It is recommended as a matter of high priority that treated wastewater is considered and made a reliable alternative source in water resources management. Agricultural wastewater reuse can effectively contribute to fill the increasing gap between water demand and water availability particularly in semi-arid areas. In future, further work is needed to examine organic and toxic constituents in wastewater and more intensive sampling and studies to measure any change of chemical elements in wastewater, irrigated soil and plant.

\section{Acknowledgements}

Many thanks to Ministry of Higher Education and Scientific Research, Research and Development Office, without their financial support the work would have not been done.

\section{REFERENCES}

[1] G. Zulu, M. Toyota and S. Misawa, "Characteristics of Water Reuse and its Effects on Paddy Irrigation System Water Balance and the Riceland Ecosystem," Agricultural Water Management, Vol. 31, No. 3, October 1996, pp. 269-283.

[2] J. D. Oster, "Irrigation with Poor Quality Water," Agricultural Water Management, Vol. 25, No. 3, July 1994, pp. 271-297.

[3] WHO, "A Regional Overview of Wastewater Management and Reuse in the Eastern Mediterranean Region," World Health Organization, Regional Office for the Eastern Mediterranean Regional, California Environmental Health Association, 2005.

[4] C. A. Scott, N. I. Faruqui and L. Raschid-Sally, "Wastewater Use in Irrigated Agriculture: Confronting the Livelihood and Environmental Realities," CABI Publishing, Wallingford, 2004.

[5] M. Qadir, D. Wichelns, L. Raschid-Sally, P. S. Minhas, P. Drechsel, A. Bahri and P. McKornick, "Agricultural Use of Marginal Quality Water-Opportunities and Challenges," In: D. Molden, Ed., Water for Food, Water and life: A Comprehensive Assessment of Water Management in Agriculture, Earthscan, London, 2007.

[6] B. Jimenez and T. Asano, "International Survey on Water Reuse," International Water Association Publishing, London, 2008.

[7] S. S. Al-Salem, "Environmental Considerations for WasteWater Reuse in Agriculture," Water Science and Technology, Vol. 33, No. 10-11, 1996, pp. 345-353.

[8] M. J. Mohammad and N. Mazahreh, "Changes in Soil Fertility Parameters in Response to Irrigation of Forage Crops with Secondary Treated Wastewater," Communications in Soil Science and Plant Analysis, Vol. 34, No. 910, May 2003, pp. 1281-1294.

[9] L. S. McNeill, M. N. Almasri and N. Mizyed, "A Sustainable Approach for Reusing Treated Wastewater in Agricultural Irrigation in the West Bank-Palestine," Desalination, Vol. 248, No. 1-3, 2009, pp. 315-321.

[10] H. Al-Hamaiedeh and M. Bino, "Effect of Treated Grey Water Reuse in Irrigation on Soil and Plants," Desalination, Vol. 256, No. 1-3, 2010, pp. 115-119.

[11] I. Papadopoulos, "Wastewater Management for Agriculture Protection in the Near East Region," Technical Bulletin, FAO, Regional Office for the Near East, Cairo, Egypt, 1995.

[12] EPA, "Guidelines for Water Reuse," EPA625-R-04/018, US Environmental Protection Agency, Cincinnati, 2004.

[13] WHO, "Health Guidelines for the Use of Wastewater in Agriculture and Aquaculture," Report of a WHO Scientific Group, Geneva, 2006.

[14] W. K. Al-Zubari, "Towards the Establishment of a Total Water Cycle Management and Re-Use Program in the GCC Countries," Desalination, Vol. 120, No. 1-2, 1998, pp. 3-14.

[15] R. K. Yadav, B. Goyal, R. K. Sharma, S. K. Dubey and P. S. Minhas, "Post-Irrigation Impact of Domestic Sewage Effluent on Composition of Soil, Crop and Ground Water-A Case Study," Environmental International, Vol. 28, No. 6, December 2002, pp. 481-486.

[16] M. Qadir, D. Wichelns, I. Raschid-Sally, P. G. McCornik, P. Drechsel, A. Bahri and P. S. Minhas, "The Challenges of Wastewater Irrigation in Developing Countries," Agricultural Water Management, Vol. 97, No. 4, 2009, pp. 561-568.

[17] G. Hussain and A. J. A1-Saati, "Wastewater Quality and its Reuse in Agriculture in Saudi Arabia," Desalination, Vol. 123, No. 2-3, October 1999, pp. 241-251.

[18] Y. Chen, C. X. Wang and Z. J. Wang, "Assessment of the Contamination and Genotoxicity of Irrigated with Wastewater," Journal of Plant and Soil, Vol. 261, No. 1-2, April 2004, pp. 189-196.

[19] T. Rutkowski, L. Raschid-Sally and S. Buechler, "Wastewater Irrigation in the Developing World-Two Case Studies from the Kathmandu Valley in Nepal," Agricultural Water Management, Vol. 88, No. 1-3, March 2007, pp. 83-91.

[20] J. F. Wang, G. X. Wang and H. Wanyan, "Treated Waste- 
water Irrigation Effect on Soil, Crop and Environment: Wastewater Recycling in the Loess Area of China," Journal of Environmental Sciences, Vol. 19, No. 9, 2007, pp. 1093-1099.

[21] R. I. Esteban and E. O. de Miguel, "Present and Future of Wastewater Reuse in Spain," Desalination, Vol. 218, No. 1-3, January 2008, pp. 105-119.

[22] F. Morari and L. Giardini, "Municipal Wastewater Treatment with Vertical Flow Constructed Wetland for Irrigation Reuse," Ecological Engineering, Vol. 35, No. 5, May 2009, pp. 643-653.

[23] M. Al-Shammiri, A. Al-Saffar, S. Bohamad and M. Ahmed, "Waste Water Quality and Reuse in Irrigation in Kuwait Using Microfiltration Technology in Treatment," Desalination, Vol. 185, No. 1-3, November 2005, pp. 213-225.

[24] S. B. Al-Shammiri and A. M. Shahalam, "Effluent from and Advanced Wastewater Treatment Plant-An Alternate Source of Non-Potable Water for Kuwait," Desalination, Vol. 196, No. 1-3, September 2006, pp. 215-220.

[25] M. S. Mohsen and J. O. Jaber, "Potential of Industrial Wastewater Reuse," Desalination, Vol. 152, No. 1-3, February 2002, pp. 281-289.

[26] B. Y. Ammary, "Wastewater Reuse in Jordan: Present Status and Future Plans," Desalination, Vol. 211, No. 1-3, June 2007, pp. 164-176.

[27] A. S. Al-Adili, "Geotechnical Evaluation of Baghdad Soil Subsidence and their Treatments," Ph.D. Thesis, University of Baghdad, Iraq, 1998.

[28] APHA, WWA \& WEF, "Standard Methods for Examination of Water and Wastewater," 21st Edition, American Public Health Association, Washington, D.C., 2005.

[29] F. M. Eaton, "Significance of Carbonates in Irrigated Waters," Soil Science, Vol. 69, No. 2, February 1950, pp. 127-128.

[30] US Salinity Laboratory, "Diagnosis and Improvement of Saline and Alkaline Soils," Department of Agriculture, Handbook No. 60, 1954, p. 160.

[31] L. V. Wilcox, "The Quality of Water for Irrigation Use," US Department of Agriculture, Technical Bulletin No. 962, Washington, D.C., 1948, p. 40.

[32] R. S. Ayers and D. W. Westcot, "Water Quality for Agriculture," Irrigation and Drainage Paper No. 29, FAO, Rome, 1985.

[33] M. B. Pescod, "Wastewater Treatment and Use in Agriculture," FAO Irrigation and Drainage Paper No. 47, FAO, Rome, 1985.

[34] R. K. Tatawat and C. P. Singh Chandel, "A Hydrochemical Profile for Assessing the Groundwater Quality of Jaipur City," Environmental Monitoring and Assessment, Vol. 143, No. 1-3, August 2008, pp. 337-343.

[35] W. P. Kelley, "Alkali Soils: Their Formation Properties and Reclamations," Reinhold, New York, 1951.

[36] S. Begum and M. G. Rasul, "Reuse of Stormwater for Watering Gardens and Plants Using Green Gully: A New Stormwater Quality Improvement Device (SQID)," Water
Air Soil Pollution: Focus, Vol. 9, No. 5-6, December 2009, pp. 371-380.

[37] B. Abdul-Moneim, "Protected Irrigation," Kuwait University, 1985.

[38] D. K. Todd, "Groundwater Hydrology," Wiley International Edition, John Wiley and Sons. Inc., New York, 1980.

[39] T. N. Tiwari and A. Manzoor, "Pollution of Subarnarekha River near Jamshedpur and the Suitability of its Water for Irrigation," Indian Journal of Environmental Protection, Vol. 8, 1988, pp. 494-497.

[40] C. A. Bower and M. Maasland, "Sodium Hazards of Punjab Groundwater," West Pakistan Engineering Congress Proceeding, Vol. 50, 1963, pp. 49-61.

[41] R. S. Ayers and D. W. Westcot, "Water Quality for Agriculture," Irrigation and Drainage Paper No. 29, FAO, Rome, 1976.

[42] D. L. Suarez, "Relation between pHc and Sodium Adsorption Ratio (SAR) and An Alternative Method of Estimating SAR of Soil or Drainage Waters," Soil Science Society of American Journal, Vol. 45, No. 3, 1981, pp. 469-475.

[43] N. S. Rao, "Seasonal Variation of Groundwater Quality in a part of Guntur District, Andhra Pradesh, India," Environmental Geology, Vol. 49, No. 3, January 2006, pp. 413-429.

[44] K. R. Karanth, "Hydrogeology," McGraw-Hill, New Delhi, 1989.

[45] G. Fipps, "Irrigation Water Quality Standards and Salinity Management," The Texas A \& M University System, 1998. http://www.extension.org/mediawiki/files/1/1e/Salinity document.pdf

[46] D. J. Halliwell, K. M. Barlow and D. M. Nash, "A Review of the Effects of Wastewater Sodium on Soil Physical Properties and their Implications for Irrigation Systems," Australian Journal of Soil Research, Vol. 39, No. 6, 2001, pp. 1259-1267.

[47] R. W. Tillman and A. Surapaneni, "Some Soil-Related Issues in the Disposal of Effluent on Land," Australian Journal of Experimental Agriculture, Vol. 42, No. 3, 2002, pp. 225-235.

[48] J. E. Ayers and K. K. Tanji, "Effect of Drainage on Water Quality in Arid and Semiarid Lands," In: R. W. Skaggs and J. van Schilfgaarde, Eds., Agricultural Drainage, ASA-CSSA-SSSA, Madison, 1999, pp. 831-867.

[49] J. W. van Hoorn and J. G. van Alpen, "Salinity Control, Salt Balance and Leaching Requirement of Irrigated Soil9," International Course of Land Drainage, Wageningen, the Netherlands, 1990.

[50] L. Khodapanah, W. N. A. Sulaiman and D. N. Khodapanah, "Groundwater Quality Assessment for Different Purposes in Eshtehard District, Tehran, Iran," European Journal of Scientific Research, Vol. 36, No. 4, 2009, pp. 543-553.

[51] I. Szabolcs and C. Darab, "The Influence of Irrigation Water of High Sodium Carbonate Content of Soils," Proceedings of 8th International Congress of Isss, Vol. 2, 1964, pp. 803-812. 